KUPFER, MARIA CRISTINA MACHADO. Educação para o futuro: Psicanálise e Educação. São Paulo: Escuta, 2000.162 p. .

\title{
EDUCAÇÃO PARA O FUTURO: PSICANÁLISE E EDUCAÇÃO
}

\author{
Leandro Alves Rodrigues dos Santos
}

Mestrando do Instituto de Psicologia - USP

O que podem fazer, conjuntamente, psicanalistas e educadores, pela Educação? Essa é uma questão que interroga, sutilmente, o leitor que se embrenha nas idéias de Maria Cristina Machado Kupfer sobre a delicada (e polêmica) intersecção entre Psicanálise e Educação.

Os psicanalistas, quando não são ortodoxamente clínicos, se aventuram em outros aspectos da cultura e, ainda assim, comumente duvidam da possibilidade de algum tipo de colaboração efetiva da Psicanálise para alguma intervenção nos fenômenos do cotidiano escolar. Partem de uma premissa de que cada sujeito deve ser considerado singularmente, portanto o professor ou o aluno necessitariam ser escutados individualmente, para que alguma transformação oriunda da Psicanálise possa se fazer notar.

Como pensar então, em fenômenos de amplitude social como o fracasso escolar, da indisciplina e do vandalismo que assolam algumas escolas, da desvalorização da figura do professor no imaginário social ou ainda da própria descrença sobre uma suposta garantia de ascensão socioeconômica por via de uma carreira escolar supostamente efetuada com sucesso.

Já os educadores, não entendem como alguém que ocupa um lugar de saber, não responde diretamente às questões formuladas, devolve questões no lugar de respostas, pergunta por aspectos subjetivos do educador ao invés do educando, não diz o que fazer, aponta sentidos estranhos aos discursos dos diversos atores da cena escolar, pede com freqüência para falar um pouco mais (falar o quê, afinal?) de um aluno ou de uma situação. Mas, afinal, como pode haver um diálogo, então, entre esses dois interlocutores?

Esse livro fornece alguns subsídios para que haja algum início de interlocução entre o psicanalista e o educador, pois a autora ocupa esses dois lugares em seu percurso acadêmico e profissional. É psicanalista de formação lacaniana, docente de graduação e pós-graduação no Instituto de Psicologia da Universidade de São Paulo e idealizou, além de coordenar, a Pré Escola Terapêutica Lugar de Vida. A oferta dessa instituição é caracterizada pela pesquisa, atividades de ensino e extensão, além do atendimento terapêutico de crianças portadoras de distúrbios globais do desenvolvimento, incluindo-se ai as variadas síndromes genéticas além das psicoses e autismos. Um aspecto crucial que deve ser destacado é, de que essas crianças encontram poucas chances de escolarização no sistema tradicional, dai a tentativa do grupo de profissionais (realmente multidisciplinar, composto por psicanalistas, fonoaudiólogos, médicos e outros especialistas) de arquitetar uma proposta inovadora, chamada educação terapêutica. A idéia norteadora dessa proposta é, de que por meio de um processo educacional, possa haver um espaço, potencializado pelos profissionais, para a assunção de um sujeito, em cada criança que se matricula no Lugar de Vida.

Essa aposta, tratar o aluno como sujeito e não objeto, é o resultado de um programa de pesquisa, iniciado em 1982 com sua dissertação de mestrado, que tratava da relação professor-aluno sob um olhar psicanalítico, até 1999, com sua tese de livre-docência (que gerou esse livro), 
totalizando portanto quase duas décadas de pesquisa e investigação, apontando aspectos que não são privilegiados em outras abordagens psicológicas das vicissitudes do cotidiano escolar.

Kupfer, durante os quatro capítulos que estruturam seu livro, delineia um traçado coerente, iniciando com um capítulo teórico que abarca os limites e o alcance de uma aproximação entre Psicanálise e Educação. Faz um recenseamento das idéias freudianas acerca da referida aproximação, discorrendo longamente sobre alguns pensadores clássicos da área, como Catherine Millot e outros.

Mas, se interpõe à afirmação clássica millotiana de que a Pedagogia deve ser deixada para os pedagogos, contrapondo com idéias de Annie Cordiê e Maud Mannonni (com sua escola experimental de Bonneuil, referência-mor do Lugar de vida), autoras que discordam de Millot e reacendem as discussões referentes ao tema, dentro da comunidade psicanalítica.

Ao citar os autores que estendem as possíveis intersecções da Psicanálise com outros campos de saber, Kupfer solidifica suas idéias amparando-se em pensadores que afirmam que todo laço social, pressupõe, de alguma forma, uma interferência do inconsciente. Um bom exemplo seria no caso de qualquer intervenção ou ato de um adulto sobre um criança, que sob o disfarce de um ato educativo, carrega as cores do desejo adulto, o que pressupõe um questionamento ético acerca do ato, como sugerem seus pares e colaboradores, Leandro de Lajonquiere e Alfredo Jerusalinsky, psicanalistas de origem argentina, mas residentes e atuantes no Brasil.

No segundo capitulo, há um recorte especifico na questão da educação especial, considerada como um campo propício para a contribuição efetiva do referencial psicanalítico, enquanto estruturante de um plano de ação, frente ao projeto de escolarização de crianças psicóticas e autistas.

No desenrolar do capítulo, há uma exposição histórica dos conceitos de psicose e autismo, desde 1800, com Jean Itard, passando por Kanner, na década de 40. O diagnóstico, os aspectos orgânicos (e a leitura organicista) e o tratamento dessas crianças são contemplados de uma maneira imparcial e critica, permitindo ao leitor interessado, uma ampliação dos conhecimentos, facilitando a apresentação de três instituições que atuam por meio do "casamento" - termo cunhado pela autora - entre a Psicanálise e educação especial.

São elas, a Escola Experimental de Bonneuil, localizada na França, a Le Courtil, originária da Bélgica e a representante brasileira, chamada Centro de Pesquisa em Psicanálise e Linguagem, situada em Pernambuco, mais especificamente na cidade de Recife.

As instituições acima, são referenciadas como inspiradoras da Pré Escola Terapêutica Lugar de Vida, objeto do terceiro capítulo, onde o termo "educação terapêutica" é apresentado e legitimado como representante da proposta de uma escolarização para o sujeito que "habita" as crianças que podem set consideradas como portadoras de distúrbios globais de desenvolvimento. Para isso, a autora delimita três eixos fundamentais: a inclusão escolar, que é monitorada pelo projeto Ponte, que fornece suporte e auxilio logístico para as crianças do Lugar de Vida que apresentam condições de freqüentar a escola tradicional. O campo institucional é o segundo eixo, que funda a estrutura, a prática e a leitura dos fenômenos cotidianos do Lugar de Vida, representando um laboratório com produção consistente acerca da idéia norteadora. Os aspectos cognitivos, de socialização, culturais e de singularidade de cada criança são levados em conta, o que distancia essa instituição de outras que atendem essa clientela, pois o aluno certamente tem voz, escutada pelos profissionais que, balizados pela Psicanálise, estão produzindo um 
conhecimento respeitável sobre as peculiaridades dessas crianças.

O terceiro eixo, provavelmente interessará aos psicólogos escolares e professores que acreditam na possibilidade da existência de outros modos de compreensão da inteligência e funcionamento cognitivo. Há diversos relatos de experiências sobre alfabetização, simbolização e subjetivação de crianças da instituição, com cores psicanalíticas, mas acessíveis ao leitor leigo ou iniciante nesse campo.

O último capítulo aprofunda alguns tópicos que a autora aponta como fundamentais para se imaginar uma educação para o sujeito, iniciando primeiramente pela noção de sujeito, conceito psicanalítico fundamental. Mas, para que o aluno seja tomado como sujeito, é necessário que o educador também o seja, que envolva sua prática com aquilo que lhe é mais peculiar, o estilo. Para isso, Lacan é citado de forma parcimoniosa, alinhavando com outros autores um fio condutor que ampara essa idéia ambiciosa, que pode ser pensada de forma análoga à ética psicanalítica; tratar o outro como sujeito, não objeto e não aceitar o lugar de objeto frente a um outro. Talvez ai resida uma colaboração importantíssima da Psicanálise para a Educação. Outros aspectos relevantes desse capítulo são as tentativas de "clareagem" - termo cunhado pela psicanalista francesa Maud Mannonni - dos fenômenos do cotidiano escolar, como por exemplo, a leitura da instituição escolar pela Psicanálise, da violência, do aluno anti-social, do lugar que o professor representa atualmente nos discursos sociais, da escola pública e de seu fracasso (escolar) em oferecer escolarização de boa qualidade para a clientela.

Não há, nesse livro, uma postura ingênua ou reducionista frente ao desafio de se pensar e produzir conhecimento nessa área, questiona enfaticamente sobre a responsabilidade individual, quer seja de educadores ou psicanalistas, do sujeito sobre a Cultura, sobre os laços sociais e os empurra..." a buscar, incessantemente, modos de fazer da educação um instrumento que tome mais digna a sustentação do mal-estar na civilização"(p.148).

\section{ENDEREÇO}

Rua Augusta, 135, Vila Helena

CEP: 09175-470 - Santo André - SP

Fones: (OXX11) 49901353

(OXX11) 50523909

E-mail: leandro.psi@uol.com.br 